\title{
Neural Growth Factor Stimulates Proliferation of Spinal Cord Derived-Neural Precursor/Stem Cells
}

\author{
Youngmin Han, M.D., Kyoung-Tae Kim, M.D. \\ Department of Neurosurgery, Kyungpook National University Hospital, Daegu, Korea
}

\begin{abstract}
Objective : Recently, regenerative therapies have been used in clinical trials (heart, cartilage, skeletal). We don't make use of these treatments to spinal cord injury (SCl) patients yet, but regenerative therapies are rising interest in recent study about SCI. Neural precursor/stem cell (NPSC) proliferation is a significant event in functional recovery of the central nervous system (CNS). However, brain NPSCs and spinal cord NPSCs (SC-NPSCs) have many differences including gene expression and proliferation. The purpose of this study was to investigate the influence of neural growth factor (NGF) on the proliferation of SC-NPSCs.

Methods : NPSCs $\left(2 \times 10^{4}\right)$ were suspended in $100 \mu \mathrm{L}$ of neurobasal medium containing NGF-7S (Sigma-Aldrich) and cultured in a 96-well plate for 12 days. NPSC proliferation was analyzed five times for either concentration of NGF (0.02 and $2 \mathrm{ng} / \mathrm{mL})$. Sixteen rats after SCl were randomly allocated into two groups. In group 1 (SCl-vehicle group, $n=8$ ), animals received $1.0 \mathrm{~mL}$ of the saline vehicle solution. In group 2 (SCl-NGF group, $n=8$ ), the animals received single doses of NGF (Sigma-Aldrich). A dose of $0.02 \mathrm{ng} / \mathrm{mL}$ of NGF or normal saline as a vehicle control was intra-thecally injected daily at 24 hour intervals for 7 days. For Immunohistochemistry analysis, rats were sacrificed after one week and the spinal cords were obtained. Results : The elevation of cell proliferation with $0.02 \mathrm{ng} / \mathrm{mL}$ NGF was significant $(p<0.05)$ but was not significant for $2 \mathrm{ng} / \mathrm{mL}$ NGF. The optical density was increased in the NGF $0.02 \mathrm{ng} / \mathrm{mL}$ group compared to the control group and NGF $2 \mathrm{ng} / \mathrm{mL}$ groups. The density of nestin in the SCl-NGF group was significantly increased over the SCl-vehicle group $(p<0.05)$. High power microscopy revealed that the density of nestin in the SCl-NGF group was significantly increased over the SCl-vehicle group.

Conclusion : SC-NPSC proliferation is an important pathway in the functional recovery of SCI. NGF enhances SC-NPSC proliferation in vitro and in vivo. NGF may be a useful option for treatment of SCl patients pending further studies to verify the clinical applicability.
\end{abstract}

Key Words : Neural growth factor $\cdot$ Spinal cord neural precursor/stem cell $\cdot$ Spinal cord injury.

\section{INTRODUCTION}

Traumatic spinal cord injury (SCI) is a serious and complex condition that causes severe and permanent dysfunction and disability. Research to improve and even reverse SCI damage has recently benefited from advancements in the knowledge of the pathophysiology, including the potential of stem cell therapy.

SCI pathophysiology comprises the direct, primary injury caused by the initial mechanical trauma and secondary injury due to a subsequent series of secondary degenerative processes that result in cell apoptosis. Primary injury is permanent, but although secondary injury should be preventable, no novel and efficient treatment options exist ${ }^{3,4,26,28,31)}$.

Recently, regenerative therapies were used in clinical trials (heart, cartilage, skeletal) ${ }^{2,29,36)}$. We don't make use of these treat- ments to SCI patients yet, but regenerative therapies are rising interest in recent study about SCI.

Neural precursor/stem cells (NPSCs) are capable of dividing, migrating, and differentiating into neurons. NPSC proliferation is a significant event in functional recovery of the central nervous system $(\mathrm{CNS})^{23,24,37)}$. Also, NPSC has been known to be effective for functional recovery in SCI according to the several previous studies $^{17,22,33)}$. Nerve growth factor (NGF), brain-derived neurotrophic factor (BDNF), insulin growth factor-1 (IGF-1), and basic fibroblast growth factor (bFGF) are essential neurotrophic factors involving in inducing the proliferation and differentiation of NPSCs ${ }^{1,8,11,12,37)}$. It is known from previous studies that several neurotrophic factors affect the proliferation of spinal cord NPSCs (SC-NPSCs). In addition, there have been studies on the effect of NGF on brain NPSC ${ }^{5,6,18)}$. However, both brain

- Received : February 13, 2016 • Revised : May 10, 2016 •Accepted : June 8, 2016

- Address for reprints : Kyoung-Tae Kim, M.D.

Department of Neurosurgery, Kyungpook National University Hospital, 130 Dongdeok-ro, Jung-gu, Daegu 41944, Korea

Tel : +82-53-420-5657, Fax : +82-53-423-0504, E-mail : nskimkt7@gmail.com

- This is an Open Access article distributed under the terms of the Creative Commons Attribution Non-Commercial License (http://creativecommons.org/licenses/by-nc/3.0) which permits unrestricted non-commercial use, distribution, and reproduction in any medium, provided the original work is properly cited. 
NPSC and SC-NPSC have significant differences that include gene expression and proliferation ${ }^{19,25)}$. The purpose of this study, therefore, is to investigate the influence of NGF on the proliferation of SC-NPSCs.

\section{MATERIALS AND METHODS}

\section{Animals}

All animal experiments in this study involved adult male Sprague-Dawley (SD) rats weighing 290-310 g (Samtako Bio, Osan, Korea) that were cared for according to the national institutes of health guide for the care and use of laboratory animals. The animal resources and care committee of our university approved all surgical procedures. Animals were housed in a temperature controlled room using alternating 12-hour (hr) cycles of light and dark.

\section{Culture of adult SC-NPSCs}

Dissected rat spinal cord was chopped up using microscissors and incubated in a cocktail containing papain $(0.1 \%$, Worthington Biochemical Corp., Lakewood, NJ, USA), dispase $(0.1 \%$, Boehringer Mannheim, Mannheim, Germany), DNase (0.01\%, Worthington Biochemical, Lakewood, NJ, USA), and $\mathrm{MgSO}_{4}$ (12.4\%) in Hanks balanced salt solution (Invitrogen, Carlsbad, CA, USA) with glucose $(0.45 \%)$ for $30 \mathrm{~min}$ at $37^{\circ} \mathrm{C}$. The dissociated cells were cultured to form neurospheresin a neurobasal medium containing B-27 (Invitrogen, Carlsbad, CA, USA), glutamine ( $2 \mathrm{mmol} / \mathrm{L})$, penicillin/streptomycin $(0.1 \mathrm{~g} / \mathrm{mL}$, Invitrogen, Carlsbad, CA, USA), FGF-2 (20 ng/mL, R\&D Systems, Minneapolis, MN, USA), and heparin ( $2 \mathrm{mg} / \mathrm{mL}$, Sigma-Aldrich, St. Louis, MO, USA). After 7 days, the neurospheres were dissociated with Accutase (Innovative Cell Technologies, San Diego, CA, USA) and $5 \times 10^{5}$ NPSCs were grown in plates or dishes containing $5 \mathrm{~mL}$ of culture medium. For identify the NPSC gene, we performed the NPSC gene chip analysis in primary culture.

\section{Cell proliferation assay}

NPSCs $\left(2 \times 10^{4}\right)$ were suspended in $100 \mu \mathrm{L}$ of neurobasal medium containing NGF-7S (Sigma-Aldrich, St. Louis, MO, USA) and cultured in a 96-well plate for 12 days. NGF concentration was 0.02 or $2 \mathrm{ng} / \mathrm{mL}$. Culture medium was changed four times as once per 3 days. A $20-\mu \mathrm{L}$ cell proliferation assay solution containing the tetrazolium compound MTS (CellTiter 96 Aqueous One Solution; Promega, Madison, WI, USA) was added to a well containing cultured cells and incubated for $2.5 \mathrm{hr}$ at $37^{\circ} \mathrm{C}$. The optical density was measured at $490 \mathrm{~nm}$ with a microplate spectrophotometer. The same volume of culture medium with the assay solution was used as a blank.

\section{Spinal cord injury and administration of NGF}

$\mathrm{SD}$ rats $(\mathrm{n}=16)$ were randomly allocated into two groups. In group 1 (SCI-vehicle, $\mathrm{n}=8$ ), animals received $1.0 \mathrm{~mL}$ of the saline vehicle solution. In group $2(\mathrm{SCI}-\mathrm{NGF}, \mathrm{n}=8)$, the animals re- ceived single doses of NGF (Sigma-Aldrich, St. Louis, MO, USA). Rats were anesthetized intra-peritoneally with a mixture of xylazine $(10 \mathrm{mg} / \mathrm{kg})$ and ketamine $(60 \mathrm{mg} / \mathrm{kg})$. After laminectomy at T9-10, a modified aneurysm clip with a closing force of 30 grams (Aesculap, Tuttlingen, Germany) was held in an applicator. The clip applied vertically to the exposed spinal cord for a 2 minutes compression. Bladders were manually emptied twice daily until spontaneous voiding occurred. A dose of $0.02 \mathrm{ng} / \mathrm{mL}$ of NGF or normal saline as a vehicle control was intra-thecally injected daily at $24 \mathrm{hr}$ intervals for 7 days.

\section{Immunohistochemistry of nestin}

For immunohistochemistry (IHC) analysis, rats were sacrificed after one week and the spinal cords were obtained. Spinal cord tissue was sectioned at a thickness of $30 \mu \mathrm{m}$ on a cryostat and sections were floated on the surface of $0.1 \mathrm{M}$ phosphate buffer. To detect nestin (marker for neural stem cells), 5- and 6-mm sections of rostral spinal cord were selected. The sections were blocked with $4 \%$ normal serum in $0.5 \%$ Triton X-100 for $1 \mathrm{hr}$ at room temperature and incubated over night at $4^{\circ} \mathrm{C}$ with a 1 : 2000 dilution of mouse monoclonal anti-nestin (R\&D Systems, Minneapolis, MN, USA). Sections were incubated in $0.1 \mathrm{M}$ phosphate buffer containing $4 \%$ normal serum and $0.5 \%$ Triton $\mathrm{X}-100$ for $2 \mathrm{hr}$ at $25^{\circ} \mathrm{C}$ on a shaker, and then in primary antiserum in $0.1 \mathrm{M}$ phosphate buffer containing $4 \%$ normal serum and $0.5 \%$ Triton $\mathrm{X}-100$ for $12 \mathrm{hr}$ at $25^{\circ} \mathrm{C}$. After rinsing $(3 \times 10$ $\mathrm{min}$ ) in $0.1 \mathrm{M}$ phosphate buffer, sections were exposed to a 1 : 200 dilution of biotinylated anti-mouse IgG (Sigma-Aldrich, St. Louis, MO, USA) in $0.1 \mathrm{M}$ phosphate buffer containing $4 \%$ normal serum and $0.5 \%$ Triton $\mathrm{X}-100$ at $25^{\circ} \mathrm{C}$ for $2 \mathrm{hr}$. The sections were then incubated in a $1: 50$ dilution of avidin-biotinylated horseradish peroxidase (Vector Laboratory, Burlingame, CA, USA) in $0.1 \mathrm{M}$ phosphate buffer for $2 \mathrm{hr}$ and rinsed $(3 \times 10 \mathrm{~min})$ in $0.25 \mathrm{M}$ Tris. Staining was visualized by reaction with 3, 3'-diaminobenzidine tetrahydrochloride (DAB) and hydrogen peroxide in $0.25 \mathrm{M}$ Tris for 3-10 minutes using a DAB reagent set (Kierkegaard \& Perry, Gaithersburg, MD, USA). All sections were washed out in $0.1 \mathrm{M}$ phosphate buffer and mounted on Superfrost Plus slides (Fisher, Pittsburgh, PA, USA). Sections were dried overnight at $37^{\circ} \mathrm{C}$. The tissues were photographed using a Zeiss Axiopan microscope with high power DIC optics (Carl Zeiss, Jena, Germany). The images were viewed on a computer monitor using a Zeiss Plan-Apochromat $40 \times$ objective (Carl Zeiss, Jena, Germany) and photographs of the ventral side of white matter of both sides were taken with a Zeiss Axio Cam HRc digital camera (Carl Zeiss, Jena, Germany). Enumeration of immune-positive cells was done using a Lab works version 4.5 computer-assisted image analyzer (UVP, Upland, CA, USA).

\section{Statistical analysis}

All statistical comparisons were computed using SPSS 17.0 (SPSS Inc., Chicago, IL, USA). Data are expressed as mean \pm 
standard error (SE) of the means. Repeated measure ANOVA was used to compare groups. Null hypotheses of no difference were rejected if $p$-values were $<0.05$.

\section{RESULTS}

\section{NGF affects SC-NPSC proliferation in vitro}

NGF concentrations of 0.02 and $2 \mathrm{ng} / \mathrm{mL}$ were used. NPSC proliferation was assayed five times for either concentration. When compared to the control group, NPSC proliferation was increased at both concentrations. The average cell proliferation was 0.39646 (optical density ratio 100) in the control group, 0.4295 (optical density ratio 108.3 ) in the $0.02 \mathrm{ng} / \mathrm{mL}$ NGF group, and 0.41478 (optical density ratio 104.6) in the $2 \mathrm{ng} / \mathrm{mL}$ NGF group. The elevation of cell proliferation with $0.02 \mathrm{ng} / \mathrm{mL}$ NGF was significant ( $p<0.05$ ), but was not significant for $2 \mathrm{ng} / \mathrm{mL}$ NGF (Fig. 1). The optical density was increased in the NGF $0.02 \mathrm{ng} / \mathrm{mL}$ group compared to the control and NGF $2 \mathrm{ng} / \mathrm{mL}$ groups (Fig. 2).

\section{NGF induces the proliferation of NPSCs after SCI}

SCI in rats was followed by an intra-thecal injection of 0.02 $\mathrm{ng} / \mathrm{mL}$ of NGF or saline ( $\mathrm{n}=8$ /group). The injections were done at 24-hr intervals for 7 days. One week after SCI, the injured

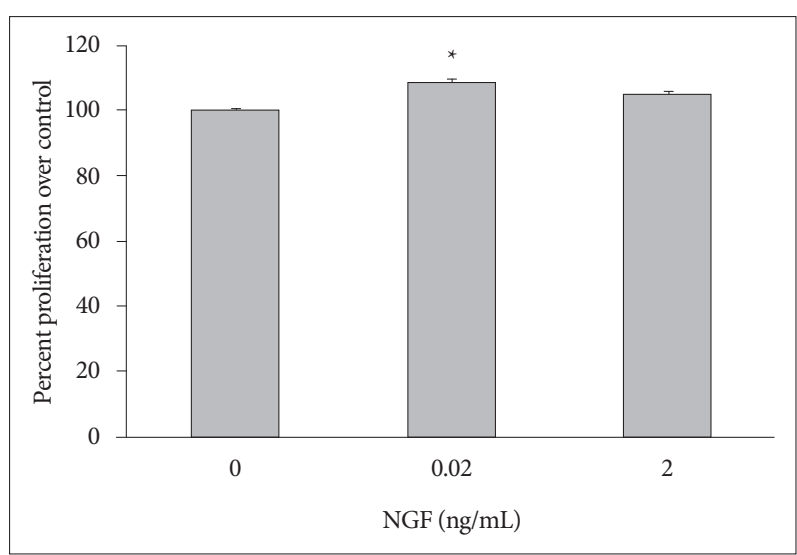

Fig. 1. Optical density ratio in the lower concentration of NGF 0.02 group ${ }^{*}$ ) was 108.3 (average of five independent determinations; $p=0.0007$ ). NPSC proliferation was significantly increased in the NGF 0.02 group $\left(^{*}\right)$ compared to the control group. NGF : nerve growth factor, NPSC : neural precursor/stem cells. rats were sacrificed, spinal cords were collected, and prepared sections of white matter of the ventral side of each spinal cord were analyzed for nestin immune reactivity. ANOVA was used to confirm density areas of nestin. The expression of nestin in the SCI-NGF group was significantly increased over the SCI-vehicle group $(p<0.05)$ (Fig. 3). High power microscopy revealed that the density of nestin in the SCI-NGF group was significantly increased over the SCI-vehicle group (Fig. 4).

\section{DISCUSSION}

Traumatic SCI causes irreversible neurological deficits in motor and sensory systems ${ }^{35)}$. Patients with traumatic SCI are at great risk of substantial morbidity and mortality. Many pathological changes after a SCI are secondary to the initial impact, and are active biological processes. To overcome permanent damage after SCI, it is important to discontinue the secondary injuries and restore the damaged spinal cord neural networks. While stem cell therapy is theoretically possible, restoration of an impaired neural network can be technically elaborate and difficult ${ }^{15,16,20,32)}$. NPSC proliferation after SCI is important in the recovery from neurological dysfunctions. The proliferated cells can differentiate to neurons, astrocytes, and oligodendro-

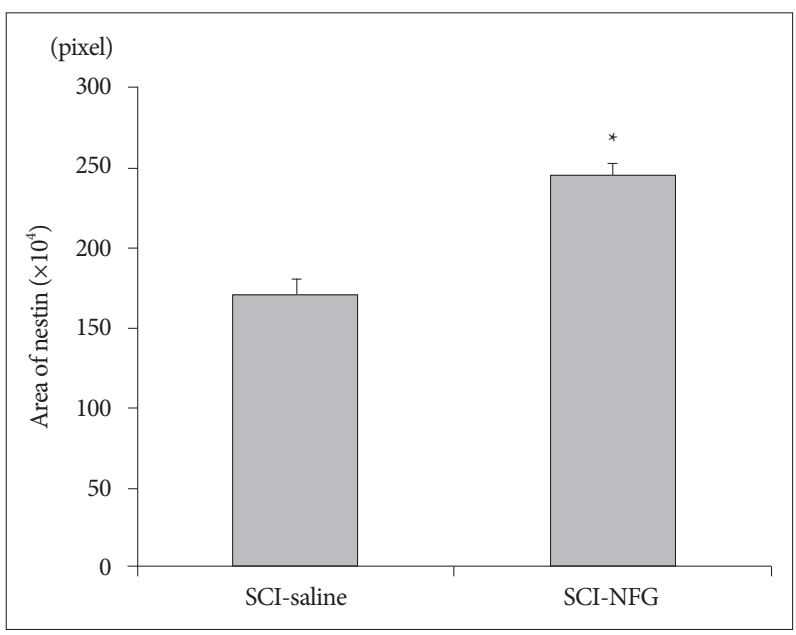

Fig. 3. The expression of nestin at the cord ventral portion in the SClNGF group (*) was significantly increased when compared to the SClvehicle group. SCI : spinal cord injury, NGF : nerve growth factor.
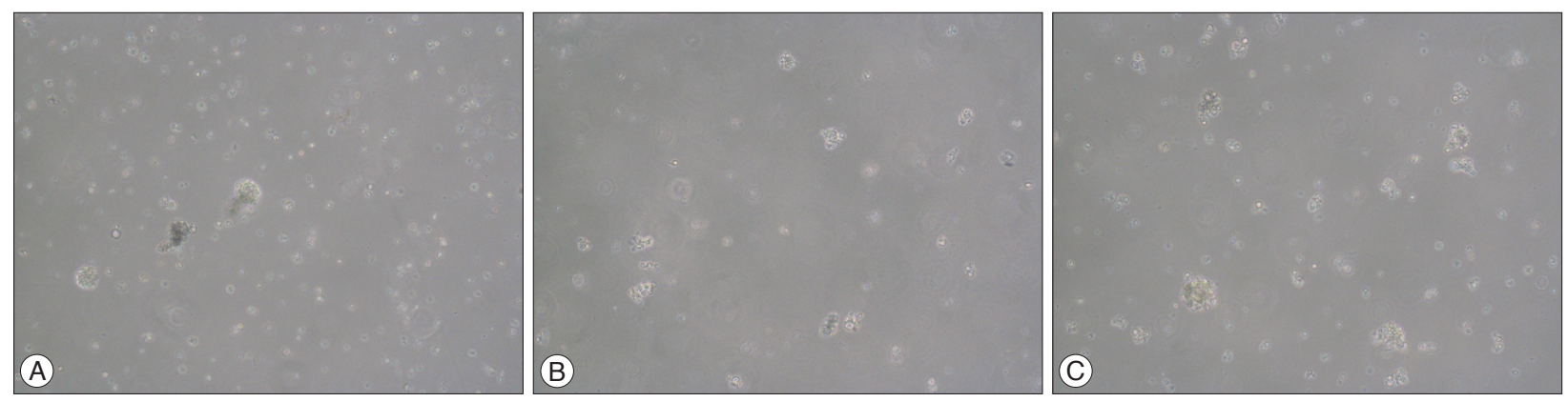

Fig. 2. The optical density of cell proliferation was increased in the NGF $0.02 \mathrm{ng} / \mathrm{mL}$ group (A) compared to the control group (B) and the NGF $2 \mathrm{ng} / \mathrm{mL}$ group (C) (original magnification, $\times 10$ ). NGF : nerve growth factor. 

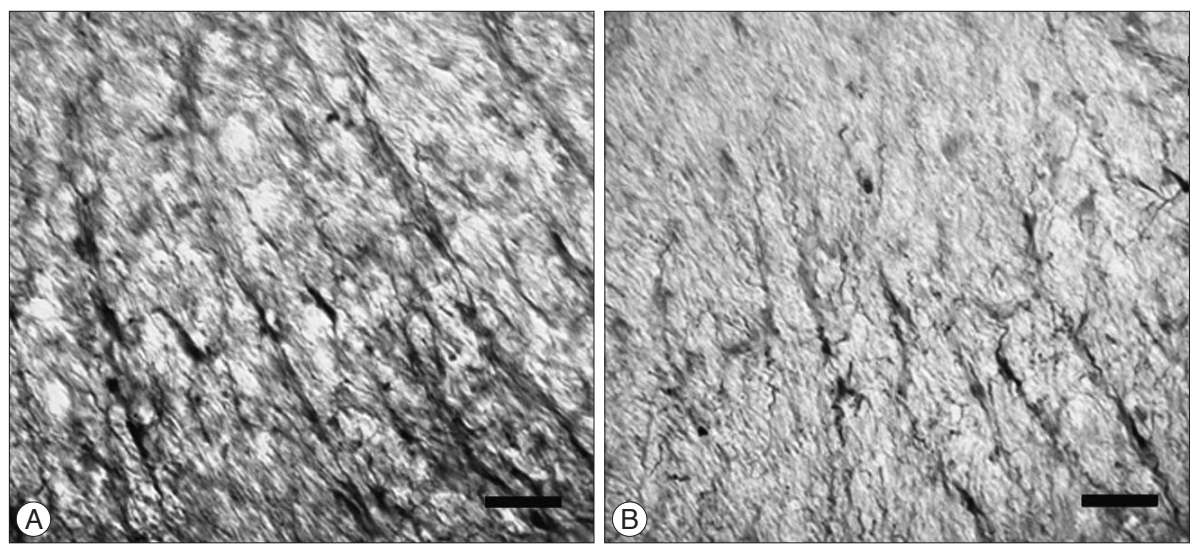

Fig. 4. High power microscopy revealed that the density of nestin in the SCl-NGF group (A) was significantly increased compared to the SCl-vehicle group (B). The black bars denote $50 \mathrm{um}$. SCl : spinal cord injury, NGF : nerve growth factor.

cytes. Also, NPSCs improve angiogenesis that enable endogenous repair and axonal outgrowth ${ }^{10,17,22)}$.

It is well known that NGF can promote brain NPSC proliferation $^{5,6,18)}$. However, brain NSPCs and SC-NPSCs are markedly different, such as in gene expression and cell proliferation ${ }^{19,25)}$. NGF effect on SC-NPSCs is unclear in spinal cord, reflecting the different pathology of SCI from brain injury.

In present study, NGF affected proliferation of SC-NPSCs. In vitro, SC-NPSC proliferation was increased in a NGF dose-related fashion compared to the control group. SC-NSPCs was significantly enhanced in the presence of $0.02 \mathrm{ng} / \mathrm{mL}$ NGF, but was not $2 \mathrm{ng} / \mathrm{mL}$ NGF. Adverse effects, such as aberrant sympathetic and sensory neurite sprouting ${ }^{27,39)}$, and weight loss ${ }^{38)}$ are observed in previous studies on brain NGF. Also, it is claimed that there is an optimal dose with a maximal effect of NGF although slight difference exists in accordance with used animals and types of tissues (brain, spinal cord, etc. ${ }^{27,38,39)}$. In this study, we evaluated only two concentrations of NGF (0.02 and $2 \mathrm{ng} / \mathrm{mL})$ and we cannot be sure that this result is most accurate value. However, $0.02 \mathrm{ng} / \mathrm{mL}$ of NGF is statistically significant value in vitro study, and we used this concentration of NGF in vivo study.

Intra-thecal injection of NGF to SCI rats increased the density of nestin on the cord ventral portion. This result is consistent with the in vitro findings. NGF promotes NPSC proliferation in brain injury ${ }^{7,9,30)}$. NGF is the first and most comprehensively studied neurotrophic factor. In vitro, NGF can induce various neural stem cells, embryonic stem cells, and mesenchymal stem cells from different species to differentiate into specific neurons ${ }^{14,40)}$. The present results reveal the same effect in spinal cord.

There are several limitations of our study. First, neural differentiation was not evaluated in this study, but NGF is mainly correlated proliferation of NPSC ${ }^{5,6,18)}$. So this study focused on NPSC proliferation in vitro and in vivo. Second, SCI rats were injected intra-thecally. This is an invasive procedure that can directly injure the spinal cord. However, NGF does not pass the bloodbrain barrier ${ }^{23,2434)}$. Thus, intra-thecal injection is necessary to evaluate the influence of NGF effect on spinal cord. The method has been established for SCI model ${ }^{13,21)}$. Third, we did not examine functional recovery. It has been known from previous studies that NPSC is helpful for functional recovery in $\mathrm{CNS}^{23,24,37)}$. When in this study the fact is taken into consideration that NGF stimulates the proliferation of SC-NPSC, it is assumed that NGF contributes to functional recovery in SCI. However, further studies are required to identify the clinical effect of NGF in the future.

\section{CONCLUSION}

SC-NPSC is an important pathway in the functional recovery of SCI. NGF enhances SC-NPSC proliferation in vitro and in vivo. NGF may be a useful option for treatment of SCI patients pending further studies to verify the clinical applicability.

\section{- Acknowledgements}

This research was supported by Basic Science Research Program through the National Research Foundation of Korea (NRF) funded by the Ministry of Science, ICT \& Future Planning (NRF-2015R1C1A1A01056299).

\section{References}

1. Ahmed S, Reynolds BA, Weiss S: BDNF enhances the differentiation but not the survival of CNS stem cell-derived neuronal precursors. J Neurosci 15 : 5765-5778, 1995

2. Al-Daccak R, Charron D : Allogenic benefit in stem cell therapy : cardiac repair and regeneration. Tissue Antigens 86 : 155-162, 2015

3. Anderson DK, Hall ED : Pathophysiology of spinal cord trauma. Ann Emerg Med 22 : 987-992, 1993

4. Beattie MS : Inflammation and apoptosis : linked therapeutic targets in spinal cord injury. Trends Mol Med $10: 580-583,2004$

5. Chen SQ, Cai Q, Shen YY, Cai XY, Lei HY : Combined use of NGF/ $\mathrm{BDNF} / \mathrm{bFGF}$ promotes proliferation and differentiation of neural stem cells in vitro. Int J Dev Neurosci 38 : 74-78, 2014

6. Choi KC, Yoo DS, Cho KS, Huh PW, Kim DS, Park CK : Effect of single growth factor and growth factor combinations on differentiation of neural stem cells. J Korean Neurosurg Soc 44 : 375-381, 2008

7. Duggal N, Schmidt-Kastner R, Hakim AM : Nestin expression in reactive astrocytes following focal cerebral ischemia in rats. Brain Res 768 : 1-9, 1997

8. Ghosh A, Greenberg ME : Distinct roles for bFGF and NT-3 in the regulation of cortical neurogenesis. Neuron $15: 89-103,1995$

9. Holmin S, Almqvist P, Lendahl U, Mathiesen T : Adult nestin-expressing subependymal cells differentiate to astrocytes in response to brain injury. Eur J Neurosci 9 : 65-75, 1997 
10. Iwai H, Nori S, Nishimura S, Yasuda A, Takano M, Tsuji O, et al. : Transplantation of neural stem/progenitor cells at different locations in mice with spinal cord injury. Cell Transplant 23 : 1451-1464, 2014

11. Joannides AJ, Webber DJ, Raineteau O, Kelly C, Irvine KA, Watts C, et al. : Environmental signals regulate lineage choice and temporal maturation of neural stem cells from human embryonic stem cells. Brain 130 (Pt 5) : 1263-1275, 2007

12. Jordan PM, Ojeda LD, Thonhoff JR, Gao J, Boehning D, Yu Y, et al. : Generation of spinal motor neurons from human fetal brain-derived neural stem cells : role of basic fibroblast growth factor. J Neurosci Res 87 : 318332,2009

13. Kim KT, Kim HJ, Cho DC, Bae JS, Park SW : Substance P stimulates proliferation of spinal neural stem cells in spinal cord injury via the mitogen-activated protein kinase signaling pathway. Spine J $15: 2055-2065$, 2015

14. Kuo YC, Shih KH, Yang JT : Capillary electrophoresis of bone marrow stromal cells with uptake of heparin-functionalized poly(lactide-co-glycolide) nanoparticles during differentiation towards neurons. Electrophoresis $31: 315-323,2010$

15. Kwon BK, Fisher CG, Dvorak MF, Tetzlaff W : Strategies to promote neural repair and regeneration after spinal cord injury. Spine (Phila Pa 1976) 30 (17 Suppl) : S3-S13, 2005

16. Kwon BK, Tetzlaff W, Grauer JN, Beiner J, Vaccaro AR : Pathophysiology and pharmacologic treatment of acute spinal cord injury. Spine J 4 : 451464, 2004

17. Li J, Lepski G : Cell transplantation for spinal cord injury : a systematic review. Biomed Res Int 2013 : 786475, 2013

18. Liu F, Xuan A, Chen Y, Zhang J, Xu L, Yan Q, et al. : Combined effect of nerve growth factor and brain derived neurotrophic factor on neuronal differentiation of neural stem cells and the potential molecular mechanisms. Mol Med Rep 10 : 1739-1745, 2014

19. Liu RH, Morassutti DJ, Whittemore SR, Sosnowski JS, Magnuson DS : Electrophysiological properties of mitogen-expanded adult rat spinal cord and subventricular zone neural precursor cells. Exp Neurol 158 : 143-154, 1999

20. Lo V, Esquenazi Y, Han MK, Lee K : Critical care management of patients with acute spinal cord injury. J Neurosurg Sci $57: 281-292,2013$

21. Milligan ED, Hinde JL, Mehmert KK, Maier SF, Watkins LR : A method for increasing the viability of the external portion of lumbar catheters placed in the spinal subarachnoid space of rats. J Neurosci Methods 90 : 81-86, 1999

22. Nakamura $\mathrm{M}$, Okano $\mathrm{H}$ : Cell transplantation therapies for spinal cord injury focusing on induced pluripotent stem cells. Cell Res 23 : 70-80, 2013

23. Olson L : NGF and the treatment of Alzheimer's disease. Exp Neurol $124: 5-15,1993$

24. Olson L, Nordberg A, von Holst H, Bäckman L, Ebendal T, Alafuzoff I, et al. : Nerve growth factor affects 11C-nicotine binding, blood flow, EEG, and verbal episodic memory in an Alzheimer patient (case report).
J Neural Transm Park Dis Dement Sect 4 : 79-95, 1992

25. Pfenninger CV, Steinhoff C, Hertwig F, Nuber UA : Prospectively isolated CD133/CD24-positive ependymal cells from the adult spinal cord and lateral ventricle wall differ in their long-term in vitro self-renewal and in vivo gene expression. Glia 59:68-81, 2011

26. Piao MS, Lee JK, Jang JW, Kim SH, Kim HS : A mouse model of photochemically induced spinal cord injury. J Korean Neurosurg Soc 46 : 479-483, 2009

27. Rosenberg MB, Friedmann T, Robertson RC, Tuszynski M, Wolff JA, Breakefield XO, et al. : Grafting genetically modified cells to the damaged brain : restorative effects of NGF expression. Science 242 : 1575-1578, 1988

28. Rowland JW, Hawryluk GW, Kwon B, Fehlings MG : Current status of acute spinal cord injury pathophysiology and emerging therapies : promise on the horizon. Neurosurg Focus 25 : E2, 2008

29. Saeed H, Ahsan M, Saleem Z, Iqtedar M, Islam M, Danish Z, et al. : Mesenchymal stem cells (MSCs) as skeletal therapeutics - an update. J Biomed Sci $23: 41,2016$

30. Sahin Kaya S, Mahmood A, Li Y, Yavuz E, Chopp M : Expression of nestin after traumatic brain injury in rat brain. Brain Res $840: 153-157,1999$

31. Tator $\mathrm{CH}$ : Update on the pathophysiology and pathology of acute spinal cord injury. Brain Pathol 5 : 407-413, 1995

32. Tederko P, Krasuski M, Kiwerski J, Nyka I, Białoszewski D : Strategies for neuroprotection following spinal cord injury. Ortop Traumatol Rehabil $11: 103-110,2009$

33. Tsuji O, Miura K, Fujiyoshi K, Momoshima S, Nakamura M, Okano H : Cell therapy for spinal cord injury by neural stem/progenitor cells derived from iPS/ES cells. Neurotherapeutics 8 : 668-676, 2011

34. Tuszynski MH : Intraparenchymal NGF infusions rescue degenerating cholinergic neurons. Cell Transplant $9: 629-636,2000$

35. von Euler M, Seiger A, Sundström E : Clip compression injury in the spinal cord : a correlative study of neurological and morphological alterations. Exp Neurol 145 (2 Pt 1) : 502-510, 1997

36. Vonk LA, de Windt TS, Slaper-Cortenbach IC, Saris DB : Autologous, allogeneic, induced pluripotent stem cell or a combination stem cell therapy? Where are we headed in cartilage repair and why : a concise review. Stem Cell Res Ther 6 : 94, 2015

37. Wang Q, Matsumoto Y, Shindo T, Miyake K, Shindo A, Kawanishi M, et al. : Neural stem cells transplantation in cortex in a mouse model of Alzheimer's disease. J Med Invest $53:$ 61-69, 2006

38. Williams LR : Hypophagia is induced by intracerebroventricular administration of nerve growth factor. Exp Neurol 113 : 31-37, 1991

39. Winkler J, Ramirez GA, Kuhn HG, Peterson DA, Day-Lollini PA, Stewart GR, et al. : Reversible Schwann cell hyperplasia and sprouting of sensory and sympathetic neurites after intraventricular administration of nerve growth factor. Ann Neurol $41: 82-93,1997$

40. Zhang L, Jiang H, Hu Z : Concentration-dependent effect of nerve growth factor on cell fate determination of neural progenitors. Stem Cells Dev 20 : 1723-1731, 2011 